Корендович В. С., к.т.н., доцент

Центр воєнно-стратегічних досліджень Національного університету оборони України імені Івана Черняховського, Київ

\title{
Застосування багатокритеріального аналізу для пріоритетного вибору
}

Резюме. В статті наводяться методи багатокритеріального аналізу систем за декількома стратегіями для підтримки прийняття рішення щодо вибору найбільш прийнятного варіанту.

Ключові слова:багатокритеріальний аналіз, стратегія вибору, оцінка систем.

Постановка проблеми. При плануванні розвитку збройних сил завжди постають завдання вибору найбільш прийнятного варіанту за декількома стратегіями, або за низкою показників, які всебічно характеризують цей варіант чи систему. В першому випадку такими стратегіями можуть бути: важливість або цінність системи озброєння та військової техніки; можливість їх реалізації; можливість утримання/обслуговування систем тощо. У другому випадку завдання може полягати у виборі найбільш сприятливого варіанту за низкою різнопланових характеристик. В обох випадках застосовується значна кількість показників, які мають різний вимір та різний вплив (різну вагу) на прийняття рішення.

Актуальним завданням $€$ застосування підходів, що дозволяють вирішувати завдання оптимального вибору експертними методами, які потребують менше часу ніж аналітичні, але водночас є більш наглядними, дозволяють гнучко корегувати припущення в ході вирішення завдання $\mathrm{i}$ разом 3 тим передбачають застосування класичних аналітичних методів.

Аналіз основних досліджень i публікацій. Питанням багатокритеріального вибору пріоритетних варіантів проектів, систем, рішень присвячена велика кількість вітчизняних та зарубіжних праць. Основні засади вирішення багатокритеріальних завдань наведені в [1]. Вирішенню окремих завдань оптимального вибору у цивільних галузях присвячені роботи [2-4].

Метою статті $\epsilon$ : за допомогою методів експертних оцінок та властивих відповідним предметним сферам аналітичних методів запропонувати методи вирішення завдання пріоритетного вибору систем у військовій сфері за декількома стратегіями та критеріями, а також навести приклади їх практичного застосування.
Виклад основного матеріалу. Розглянемо окремо методи вибору найбільш прийнятного варіанту за декількома стратегіями та за низкою показників, які всебічно характеризують цей варіант.

Метод багатокритеріального аналізу для пріоритетного вибору за декількома стратегіями. Припустимо, що необхідно із $N$ систем озброєння вибрати таку $i$-ту систему $(i=\overline{1, N}$ ), яка найбільшою мірою задовольняє $K$ стратегіям.

Кожну $j$-та стратегію $(j=\overline{1, K})$ можливо описати низкою критеріїв $x_{j l} \quad\left(l=\overline{1, L_{j}}\right)$. Кількість критеріїв $L_{j}$ може бути різною для кожної стратегії. При цьому важливо щоб критерії повною мірою описували стратегію. Наприклад, стратегію “цінність для військ" можуть характеризувати такі критерії як: швидкий позитивний вплив на боєздатність; довговічність системи; потреба в інвестиціях; ризики, що пов'язані із впровадженням; універсальність; кошти на утримання тощо. Стратегію “можливість реалізації” можуть визначати такі критерії як: вартість; наявність підготовленого персоналу; доступ до технологій; наявність необхідного партнерства тощо. Визначити взаємообумовленість критеріїв та зменшити їх кількість можливо за допомогою матриці перехресного аналізу впливу (табл. 2).

Кожному із критеріїв $x_{j l}$ методом експертних оцінок (не виключено використання інших методів) присвоїмо вагові коефіцієнти $r_{j l}$ в діапазоні (0...1), які виражають ступінь важливості критерію для $j$-ї стратегії. Ваговий коефіцієнт $r_{j l}=0$, коли критерій зовсім не важливий для стратегії, і дорівнює 1 при умові виключної важливості критерій для даної 
стратегіi. Сума вагових коефіцієнтів має дорівнювати 1. $\sum_{l=1}^{L_{j}} r_{j l}=1,(j=\overline{1, K})$

Для j-тої стратегії визначимо рейтинг $p_{i j l} \quad(l=\overline{1, L j}), \quad$ як ступінь відповідності кожної $i$-тої системи критерію $x_{j l}$. Рейтинги $p_{i j l}$ визначаються експертними або кількісними методами в діапазоні (0..1). Рейтинг дорівнює 1 , коли система повною мірою відповідає критерію, і дорівнює 0, коли зовсім не відповідає. При цьому рейтинг $p_{i j l}$ конкретної $l$-тої характеристики для всіх систем має визначатися одним i тим же методом.

Зазначені дані для кожної $j$-ї стратегії занесемо в таблицю 1.

Оцінка $E_{i j} i$-тої системи за всіма $L_{j}$ критеріями j-тої стратегї буде визначатись формулою $E_{i j}=\sum_{l} \prod_{l=1}^{L j} r_{j l} p_{i j l},(i=\overline{1, N} ; j=\overline{1, K})$.

Чим вище оцінка $E_{i j} i$-тої системи, тим більшої мірою система відповідає визначеному j-му критерію. Вважається, що пріоритетними $\epsilon$ варіанти/системи, оцінка $E_{i j}$ яких знаходиться в діапазоні $(0,67 \ldots 1)$ для кожного j-го критерію. Системи, оцінка $E_{i j}$ яких знаходиться в діапазоні $(0,34 \ldots 0,66) \epsilon$ пріоритетними другого рівня i їх також слід взяти до уваги, решта систем не розглядаються як пріоритетні.

Для оцінки низки систем/варіантів по двом критеріям результати зручно представити у виді матриці пріоритетного вибору, рис. 1. Пріоритетними будуть системи, для яких оцінка $E_{i j}$ буде знаходитися в квадраті $(0,67 \ldots 0,67 \ldots 1)$. У випадку використання трьох критеріїв оцінка пріоритетних варіантів буде знаходитися у кубі $(0,67 \ldots 0,67 \ldots 0,67 \ldots 1)$.

Таблиця 1

\begin{tabular}{|c|c|c|c|c|c|c|}
\hline & \multicolumn{5}{|c|}{ Системи, що оцінюються за $l$-ю стратегією $(j=1)$} \\
\hline & & \multicolumn{2}{|c|}{ Система 1, $(i=1)$} & \multirow{2}{*}{$\begin{array}{c}\text { Система 2 (i=2) } \\
\ldots\end{array}$} & \multicolumn{2}{|c|}{ Система N, $(i=N)$} \\
\hline $\begin{array}{c}\text { Критерії } \\
x_{j l}(j=1)\end{array}$ & $\begin{array}{c}\text { Вагові к-ти } \\
r_{11}(l=1, L)\end{array}$ & $\begin{array}{c}\text { Рейтинг } \\
p_{11 l}\end{array}$ & $\prod_{i=1}^{L} r_{1 l} p_{11 l}$ & & $\begin{array}{c}\text { Рейтинг } \\
p_{N 1 l}\end{array}$ & $\prod_{i=1}^{L} r_{1 l} p_{N 1 l}$ \\
\hline $\begin{array}{c}\text { Критерій } \\
x_{11}\end{array}$ & $r_{11}$ & $p_{111}$ & $r_{11} p_{111}$ & $\cdots$ & $p_{N 11}$ & $r_{11} p_{N 11}$ \\
\hline $\begin{array}{c}\text { Критерій } \\
x_{12}\end{array}$ & $r_{12}$ & $p_{112}$ & $r_{12} p_{112}$ & .. & $p_{N 12}$ & $r_{12} p_{N 12}$ \\
\hline$\ldots$ & $\ldots$ & $\ldots$ & $\ldots$ & $\ldots$ & $\ldots$ & $\ldots$ \\
\hline $\begin{array}{c}\text { Критерій } \\
x_{1 L}\end{array}$ & $r_{1 L}$ & $p_{11 L}$ & $r_{1 L} p_{11 L}$ & .. & $p_{N 1 L}$ & $r_{1 L} p_{N 1 L}$ \\
\hline & $\begin{array}{l}0 \leq r_{1 l} \leq 1 \\
\sum_{i=1}^{L} r_{1 l}=1\end{array}$ & $\begin{array}{c}0 \leq p_{11 l} \leq 1 \\
l=1 \ldots L\end{array}$ & $\begin{array}{c}E_{11}= \\
\sum_{i} \prod_{i=1}^{L} r_{1 l} p_{11 l}\end{array}$ & ․ & $\begin{array}{c}0 \leq p_{11 l} \leq 1 \\
l=1 \ldots L\end{array}$ & $\begin{array}{c}E_{N L}= \\
\sum_{i} \prod_{i=1}^{L} r_{1 l} p_{N 1 l}\end{array}$ \\
\hline
\end{tabular}

варіанту здійснюється, як правило, за двома стратегіями. У випадку, коли стратегій більше двох, їх порівняння можливо провести послідовно попарно. При цьому порівняння оцінок здійснюється на полі матриці, рис. 1. Виходячи 3 цього, а також для зручності розрахунків, приймемо наступні припущення:

$$
\text { вагові коефіцієнти } \quad r_{j l}(l=\overline{1, L j})
$$

присвоюватимемо в діапазоні 0-30, при умові, що їх сума має дорівнювати 30, $\sum_{l=1}^{L} r_{j l}=30$, $(j=\overline{1, K} j=)$; оцінюватимемо в діапазоні $0 \div 10$;

кількість критеріїв для оцінки кожної із систем приймемо не більше п'яти $\left(L_{j} \leq 5\right)$, а кількість стратегій - двом $(K=2)$.

За цих припущень оцінка $E_{i j} i$-тої системи за $j$-тою стратегією буде знаходитися в діапазоні $0 \div 300$. Пріоритетними будуть системи, оцінки $E_{i j}$ яких знаходиться в діапазоні 300..200 по кожній $j$-й стратегії. Системи/варіанти, оцінка $E_{i j}$ яких знаходиться в діапазоні 200...100, також слід взяти до уваги, 
решта систем розглядаються після

додаткового вивчення.

\begin{tabular}{|c|c|c|c|c|}
\hline & \multicolumn{3}{|c|}{$\leftarrow$ СТРАТЕГІЯ 2} \\
\hline & & 1 & & 33 \\
\hline \multirow{3}{*}{ 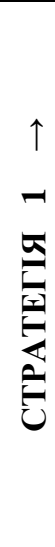 } & \multirow{2}{*}{0,67} & $\begin{array}{c}\bullet \\
\text { Пріоритет } \\
\text { А }\end{array}$ & $\begin{array}{c}\text { Пріоритет 2-го } \\
\text { рівня } \\
\text { B }\end{array}$ & $\begin{array}{c}\text { Розглянути } \\
\text { можливість у } \\
\text { довгостроковій } \\
\text { перспективі } \\
\text { — D }\end{array}$ \\
\hline & & $\begin{array}{c}\text { Пріоритет 2-го } \\
\text { рівня } \\
\text { B }\end{array}$ & $\begin{array}{c}\bullet \bullet \\
\text { Пріоритет 3-го } \\
\text { рівня } \\
\mathbf{C}\end{array}$ & $\begin{array}{c}\text { Розглянути } \\
\text { можливість у } \\
\text { довгостроковій } \\
\text { перспективі } \\
\text { D }\end{array}$ \\
\hline & $\mathbf{0 , 3 3}$ & $\begin{array}{c}\text { Розглянути } \\
\text { можливість у } \\
\text { довгостроковій } \\
\text { перспективі } \\
\text { D } \\
\end{array}$ & $\begin{array}{c}\text { Розглянути } \\
\text { можливість у } \\
\text { довгостроковій } \\
\text { перспективі } \\
\text { D } \\
\end{array}$ & $\begin{array}{c}\mathrm{He} \\
\text { розглядаються }\end{array}$ \\
\hline
\end{tabular}

- - оцінка системи за двома стратегіями

Рис. 1. Матриця пріоритетного вибору

Наведемо застосування методу на прикладі.

Приклад 1. Необхідно прийняти рішення щодо розробки системи розвідки наземних об'єктів. Пропонуються для розгляду 5 варіантів систем:

варіант “Сенсори”, оснований на розгорнутих наземних сенсорах;

варіант "Мережа", побудований на мережі, яка об'єднує існуючі засоби розвідки;

варіант "Радар", оснований на розробці спеціалізованого радару;

варіант "БПЛА”, оснований на використанні безпілотних системах;

варіант "Вертоліт", збудований на вертолітній платформі.

Оцінку зазначених систем проведемо за двома стратегіями: "Цінність для військ" та "Можливість запровадження"протягом визначеного терміну.

Для оцінки за критерієм “Цінність для військ" можливо використати наступні характеристики: оперативність (час розгортання); всепогодність; час безперервної роботи; багатофункціональність; мобільність; дальність виявлення та ймовірність викриття об'єктів.

Для оцінки "Можливість запровадження" можливо використати такі характеристики як: вартість; швидке впровадження; наявність підготовлених кадрів; наявність технологій; наявність необхідної інфраструктури; наявність системи підготовки кадрів; наявність відповідних нормативних актів.

Частина із зазначених характеристик $\epsilon$ взаємообумовленими, наприклад наявність системи підготовки кадрів та наявність підготовлених кадрів. За допомогою матриць перехресного аналізу (Табл. 2) визначимо ті характеристики, які найбільш повно характеризують стратегії.

Отже, для оцінки стратегії “Цінності для військ” будемо використовувати такі п’ять характеристик: оперативність (час розгортання); час безперервної роботи; дальність дій; ймовірність викриття противника; надійність.

Для оцінки стратегії "Можливість запровадження” аналогічним чином побудуємо матрицю перехресного аналізу, за допомогою якої приймемо для оцінки такі чотири характеристики: вартість; швидке впровадження; наявність підготовлених кадрів; наявність технологій.

Оцінки систем по двом критеріям зведемо в таблиці 3, 4

Для першої стратегї рейтинги $p_{i l l}$ характеристик кожної системи $(i=1 \ldots 5)$, за винятком двох, визначимо експертним шляхом. Рейтинги для дальності дії $\left(p_{i 13}\right)$ та ймовірності викриття об' єктів $\left(p_{i 15}\right)$ визначимо аналітичним шляхом на такому прикладі:

Припустимо, що замовник визначив, що дальність виявлення об'єктів (нормативна) повинна складати не менше 45 км, а ймовірність викриття не менше 0,8 . Припустимо, що системи, які ми оцінюємо, мають такі характеристики дальності та ймовірності виявлення об'єктів: “Сенсори” (36 км; 0,65); "Мережа"(20 км; 0,75); "Радар" (52км; 0,8); "БПЛА" (33км; 0,75); "Вертоліт" (50км; $0,85)$.

Таблиця 2 


\begin{tabular}{|c|c|c|c|c|c|c|c|c|c|c|}
\hline $\begin{array}{c}\text { Стратегія } \\
\text { “Цінність для } \\
\text { військ" }\end{array}$ & 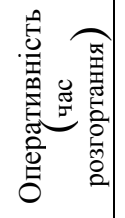 & 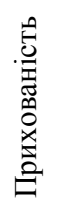 & 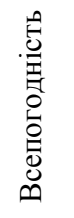 & 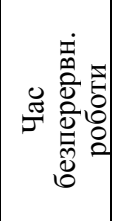 & 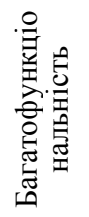 & 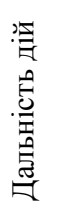 & 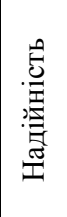 & 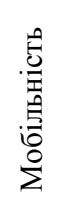 & 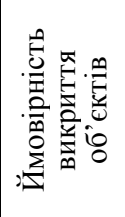 & \\
\hline Оперативність & $\mathbf{X}$ & 0 & 0 & 0 & 0 & 0 & + & 0 & 0 & +1 \\
\hline Прихованість & 0 & $\mathbf{X}$ & 0 & 0 & 0 & - & 0 & 0 & 0 & $\mathbf{0}$ \\
\hline Всепогодність & 0 & 0 & $\mathbf{X}$ & 0 & 0 & 0 & 0 & 0 & 0 & $\mathbf{0}$ \\
\hline $\begin{array}{c}\text { Час безперервн. } \\
\text { роботи }\end{array}$ & 0 & 0 & 0 & $\mathbf{X}$ & 0 & 0 & + & 0 & 0 & +1 \\
\hline $\begin{array}{c}\text { Багатофункціо- } \\
\text { нальність }\end{array}$ & 0 & 0 & 0 & 0 & $\mathbf{X}$ & 0 & 0 & 0 & 0 & $\mathbf{0}$ \\
\hline Дальність дій & 0 & 0 & 0 & 0 & 0 & $\mathbf{X}$ & 0 & 0 & + & +1 \\
\hline Надійність & 0 & 0 & 0 & 0 & 0 & 0 & $\mathbf{X}$ & 0 & + & +1 \\
\hline Мобільність & 0 & 0 & 0 & 0 & 0 & 0 & 0 & $\mathbf{X}$ & 0 & $\mathbf{0}$ \\
\hline $\begin{array}{c}\text { Ймовірність } \\
\text { викриття об'єктів }\end{array}$ & 0 & 0 & + & + & 0 & 0 & + & 0 & $\mathbf{X}$ & +3 \\
\hline
\end{tabular}

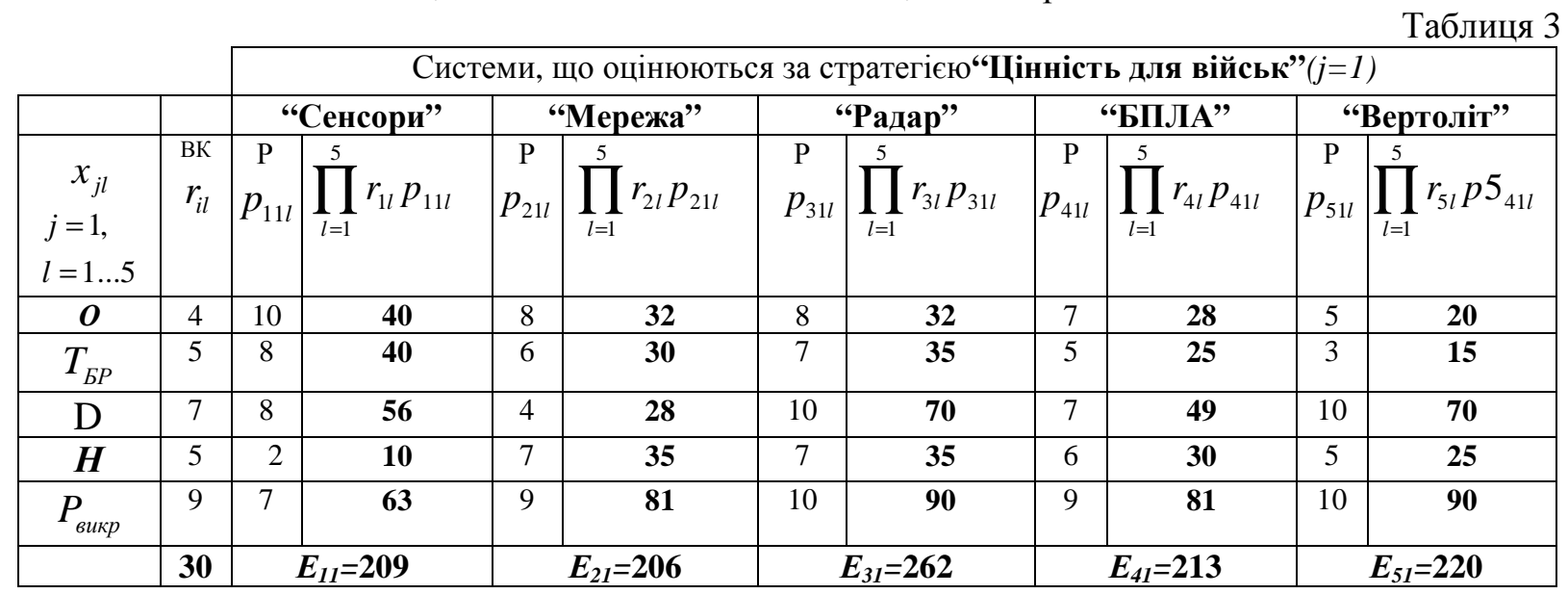

Позначення:

ВК - вагові коефіцієнти $(l=1 \ldots 5)$; $\mathrm{P}$ - рейтинг; $\boldsymbol{O}$ - оперативність; $T_{Б P}$ - час безперервної роботи;

$\mathrm{D}$ - дальність дії; $\boldsymbol{H}$ - надійність; $\boldsymbol{P}_{\text {викр }}$ - ймовірність викриття

Для наведеного прикладу ступінь відповідності систем заявленим характеристикам будемо визначатися наступним чином: по дальності - як відношення фактичної дальності виявлення до нормативної (45 км), а у випадку, коли фактична дальність більше нормативної ступінь відповідності буде дорівнювати 10; по ймовірності викриття коли реальна ймовірності викриття $(P r)$ більше нормативної, то ступінь відповідності $p_{i j l}=10$, а коли менше - як зворотна величина кількості систем, що забезпечать нормативну дальність виявлення $(P H), \quad p_{j i l}=\ln (1-P r) /(1-P H) * 10 . \quad 3$ а фізичним змістом це означає зворотну величини кількості систем, які необхідно застосувати, щоб отримати задану ймовірність викриття.

За цих умов ступінь відповідності дальності викриття та ймовірності викриття для

всіх систем будуть наступними: для "Сенсорів" $\left(36 \kappa \mathrm{s} / 45 \mathrm{\kappa м}^{*} 10=8 ; \ln (1-0,65) / \ln (1-0,8) * 10=6,5 \rightarrow 7\right)$; "Мережа" (20км $/ 45$ км* $^{*} 10=4,4 \rightarrow \mathbf{4} ; \ln (1-0,75) / \ln (1$ $0,8) * 10=8,6 \rightarrow \mathbf{9})$; "Радар" $\quad\left(52\right.$ км $/ 45$ км$^{*} 10 \rightarrow \mathbf{1 0}$; $\ln (1-0,8) / \ln (1-0,8) * 10=\mathbf{1 0})$;

"БПЛА" $\left.(33 \text { км/45км })^{*} 10 \rightarrow 7 ; \quad \ln (1-0,75) / \ln (1-0,8) * 10 \rightarrow \mathbf{9}\right) ;$ "Вертоліт" (50км/45км $\rightarrow 10 ; \rightarrow \mathbf{1 0})$.

Для стратегії "Можливість запровадження" також занесемо дані в Табл. 4.

Висновок: пріоритетними $€$ варіанти "Мережа", “БПЛА”та “Радар", які набрали більше 200 балів за всіма критеріями i знаходиться у квадраті $300 \div 200$. Разом 3 тим, не слід нехтувати іншими варіантами. Навіть зазначене орієнтовне оцінювання свідчить про необхідність проведення додаткових досліджень, а також створення систем, які б поєднували властивості наведених варіантів. 


\begin{tabular}{|c|c|c|c|c|c|c|c|c|c|c|c|}
\hline & & \multicolumn{10}{|c|}{ Системи, що оцінюються за стратегією“Можливість запровадження” $(j=2)$} \\
\hline & & \multicolumn{2}{|c|}{ "Сенсори" } & \multicolumn{2}{|c|}{ "Мережа" } & \multicolumn{2}{|r|}{ "Радар" } & \multicolumn{2}{|c|}{ “БПЛА" } & \multicolumn{2}{|c|}{ "Вертоліт" } \\
\hline $\begin{array}{c}x_{j l} \\
l=1 \ldots 4\end{array}$ & $\begin{array}{l}\mathrm{BK} \\
r_{2 l}\end{array}$ & $\begin{array}{c}\mathrm{P} \\
p_{12 l}\end{array}$ & $\prod_{l=1}^{5} r_{2 l} p_{12 l}$ & $\begin{array}{c}\mathrm{P} \\
p_{22 l}\end{array}$ & $\prod_{l=1}^{5} r_{2 l} p_{12 l}$ & $\begin{array}{l}\mathrm{P} \\
p_{32 l}\end{array}$ & $\prod_{l=1}^{5} r_{2 l} p_{13}$ & $\begin{array}{c}\mathrm{P} \\
p_{42 l}\end{array}$ & $r_{2 l} p_{4}$ & $\begin{array}{c}\mathrm{P} \\
p_{52 l}\end{array}$ & $\prod^{5} r_{2 l} p 5_{52}$ \\
\hline$C$ & 10 & 7 & 70 & 8 & 80 & 5 & 50 & 10 & 100 & 4 & 40 \\
\hline HB & 9 & 6 & 54 & 8 & 72 & 8 & 72 & 8 & 72 & 8 & 72 \\
\hline$H K$ & 5 & 7 & 35 & 8 & 40 & 7 & 35 & 9 & 45 & 7 & 35 \\
\hline \multirow[t]{2}{*}{$H T$} & 6 & 4 & 24 & 9 & 54 & 8 & 48 & 7 & 42 & 6 & 36 \\
\hline & 30 & \multicolumn{2}{|r|}{$E_{12}=183$} & \multicolumn{2}{|r|}{$E_{22}=246$} & \multicolumn{2}{|r|}{$E_{32}=205$} & \multicolumn{2}{|c|}{$E_{42}=259$} & \multicolumn{2}{|r|}{$E_{52}=183$} \\
\hline
\end{tabular}

Позначення: $\boldsymbol{C}$ - вартість; $\boldsymbol{W B}$ - швидке впровадження; $\boldsymbol{H} \boldsymbol{K}$ - наявність підготовлених кадрів; $\boldsymbol{H T}$ - наявність технологій; ВК - вагові коефіцієнти $(l=1 \ldots 4)$

Розмістимо оцінки систем на матриці пріоритетного вибору

\begin{tabular}{|c|c|c|c|c|c|}
\hline & \multicolumn{4}{|c|}{ Ł "ЦЦінність для військ" } \\
\hline & & 300 & & 100 & 0 \\
\hline \multirow{3}{*}{ 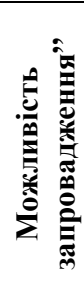 } & 300 & $\begin{array}{l}\text { Радар } \\
\text { Мережа } \\
\text { БПЛА }\end{array}$ & Вертоліт & & \\
\hline & $\begin{array}{l}200 \\
100\end{array}$ & & Сенсори & & \\
\hline & $\mathbf{0}$ & & & & \\
\hline
\end{tabular}

Слід також взяти до уваги, що кінцевий результат значною вірою залежить від значень вагових коефіцієнтів $r_{j}$, які визначаються експертами. Саме тому підбір експертів для їх визначення потребує окремої уваги. Також рекомендується визначати рейтинги $p_{i j l} 3$ використанням аналітичних/ кількісних методів, результатів випробувань тощо.

\section{Метод багатокритеріального аналізу для пріоритетного вибору систем.} Припустимо, що із $N$ систем, які застосовується у різних $M$ сценаріях/місіях та описуються $L_{j}(j=\overline{1, M}) \quad$ критеріями $x_{j l}\left(j=\overline{1, M ; l=\overline{1, L_{j}}}\right)$, необхідно вибрати таку $i$-ту систему $(i=\overline{1, N})$, яка найбільшою мірою задовольняє всім сценаріям/місіям. Кількість критеріїв для місій може бути різною.

Визначимо рейтинги $r_{i}$ для $j$-го сценарію/місії при умові, що їх сума буде дорівнювати 1, а саме: $\sum_{j=1}^{M} r_{j}=1$.
Всі системи описуються одними і тими ж критеріями $x_{j l}$, які мають відповідні вагові коефіціснти $k_{j l}, \quad$ причому $\sum_{l=1}^{L_{i}} k_{j l}=1,(j=\overline{1, M}) . \quad$ Значення цих коефіцієнтів визначається важливістю відповідного критерію для оцінки реалізації сценарію. В рамках одного сценарію вагові коефіцієнти мають однакове значення для усіх $N$ систем.

Для порівняння систем, що оцінюються для вибору, визначимо так звану “базову систему".

Порівняння $i$-тої системи 3 базовою системою по $l$-му критерію при їх застосування у $j$-му сценарії будемо проводи за якісною оцінкою $p_{i j l}$, яка може прийматиме одне із 5 значень:

$$
p_{i j l}=\left\{\begin{array}{l}
+2, \text { коли система “набагато краща" за базову; } \\
+1, \text { коли система “краща” за базову; } \\
0, \text { коли система не відрізняється від базової; } \\
-1, \text { коли система гірша за базову; } \\
-2, \text { коли система набагато гірша за базову. }
\end{array}\right.
$$


Оцінка $E_{i} i$-тої системи за всіма $L_{i}$ критеріями в $M$ сценаріями буде визначатись формулою: $\quad E_{i}=\sum_{j=1}^{M} r_{j} \sum_{i=1}^{L_{i}} \prod_{l=1}^{L} k_{j l} p_{i j l}$ $i=\overline{1, N}$
Для зручності та наглядності всі порівняльні характеристики зводяться в Табл. 5для кожного $j$-го сценарію, $j=\overline{1, M}$.

Таблиця 5

\begin{tabular}{|c|c|c|c|}
\hline & & & \\
\hline & & \multicolumn{2}{|c|}{ Системи, що порівнюються, $i=\overline{1, N}$} \\
\hline \multicolumn{4}{|c|}{ 1-й сценарій/варіант $(\boldsymbol{j}=1)$,рейтинг $\boldsymbol{r}_{1}$} \\
\hline $\begin{array}{l}\text { Критерії } \\
l=1 \ldots L j\end{array}$ & $\begin{array}{c}\text { Ваговий } \\
\text { коефіцієнт } \\
k_{j l}, l=1 \ldots L_{1}\end{array}$ & 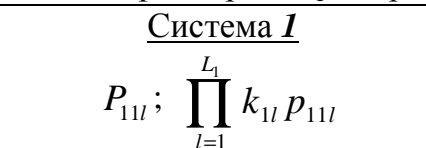 & $\frac{\text { Система } N}{P_{N 1 l} ; \prod_{l=1}^{L_{1 l}} k_{1 l} p_{N 1 l}}$ \\
\hline $\begin{array}{c}\text { Критерій } 1 \\
(l=1)\end{array}$ & $k_{11}$ & $\begin{array}{c}\text { Такий же як і } \boldsymbol{A} " \\
P_{111}=0 ; 0 \times k_{11}=0\end{array}$ & $\begin{array}{c}\text { Набагато кращий ніж “ } \boldsymbol{A} \text { ” } \\
p_{N 11}=+2 ;+2 \times k_{N 1}=2 k_{N 1}\end{array}$ \\
\hline $\begin{array}{c}\text { Критерій } 2 \\
(l=2)\end{array}$ & $k_{12}$ & $\begin{array}{c}\text { Набагато гірше } \boldsymbol{A}^{\prime \prime} \\
P_{121}=-2 ;(-2) k_{12}=-2 k_{12}\end{array}$ & $\begin{array}{c}\text { Набагато гірме “ } \boldsymbol{A} \text { ” } \\
P_{N 12}=-2 ;(-2) k_{12}=-2 k_{12}\end{array}$ \\
\hline$\ldots$ & $\ldots$ & $\ldots$ & 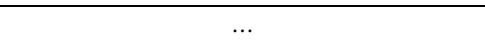 \\
\hline $\begin{array}{l}\text { Критерій } L_{l} \\
\quad\left(l=L_{l}\right)\end{array}$ & $k_{1 L_{1}}$ & $\begin{array}{c}\text { Краме ніж } \boldsymbol{A}^{\prime \prime} \\
P_{11 l}=+1 ;(+1) \times k_{1 L_{1}}=k_{1 L_{1}}\end{array}$ & $\begin{array}{c}\text { Краме ніж “ } A \text { " } \\
P_{N 1 L_{1}}=+1 ;(+1) \times k_{1 L_{1}}=k_{1 L_{1}}\end{array}$ \\
\hline $\begin{array}{l}\text { Оцінка систем за } \\
\text { сценарієм } 1\end{array}$ & & $E_{11}=\sum_{l=1}^{L_{1}} \prod_{l=1}^{L_{1}} k_{1 l} p_{11 l}$ & $E_{N 1}=\sum_{l=1}^{L_{1}} \prod_{l=1}^{L_{1}} k_{N l} p_{N 1 l}$ \\
\hline \multicolumn{4}{|c|}{ 2-й сценарій/варіант $(j=2)$, рейтинг $\boldsymbol{r}_{2}$} \\
\hline $\begin{array}{c}\text { Оцінка систем за } \\
\text { сценарієм } 2\end{array}$ & & $E_{12}=\sum_{l=1}^{4} \prod_{l=1}^{4} k_{2 l} p_{12 l}$ & $E_{N 2}=\sum_{l=1}^{L_{2}} \prod_{l=1}^{L_{2}} k_{N l} p_{N 2 l}$ \\
\hline \multicolumn{4}{|c|}{$\ldots \mathbf{N}$-й сценарій/варіант $(\boldsymbol{j}=\boldsymbol{M})$,рейтинг $r_{M}$} \\
\hline $\begin{array}{c}\text { Оцінка систем за } \\
\text { сценарієм M }\end{array}$ & & $E_{1 M}=\sum_{l=1}^{L_{M}} \prod_{l=1}^{L_{M}} k_{M l} p_{1 M l}$ & $E_{N M}=\sum_{l=1} \prod_{l=1}^{M} k_{M l} p_{N M}$ \\
\hline \multicolumn{2}{|c|}{$\begin{array}{c}\text { Оцінка систем за всіма } \\
\text { сценаріями, } \boldsymbol{E}_{\boldsymbol{i}}\end{array}$} & $\sum_{j=1}^{M} r_{j} E_{1 j}$ & $\sum_{j=1}^{M} r_{j} E_{N j}$ \\
\hline
\end{tabular}

Кращою буде система, у якої оцінка $E_{i}$ буде максимальною. Розглянемо застосування методу на прикладі:

Приклад 2. Необхідно прийняти рішення щодо закупівлі вертольоту для збройних сил. Розглядаються 3 типа вертольотів: Мi-8МСБ-В (Україна), NH90 (AirbusHelicopter), AW-149 (AgustaWestland). Miciï, до виконання яких будуть залучатися вертольоти, такі: транспортування (65\%, рейтинг транспортної місії $\left.r_{l}=0,65\right)$; вогнева підтримка $\left(5 \%, \quad r_{2}=0,05\right) ; \quad$ пошуковорятувальна $\left(15 \%, r_{3}=0,15\right)$; медична евакуація $\left(15 \%, r_{4}=0,15\right)$.
Для порівняння зазначених вертольотів будемо використовувати вертоліт Мі-8МТ. Характеристики вертольотів наведено в Табл. 6 (характеристики взяті із різних джерел і носять орієнтовний характер).

Результати порівняння характеристик вертольотів та проведення розрахунків наведені в Табл. 7, яка поєднує підрахунки для всіх сценаріїв. У Табл. 7 для розрахунку значень $E_{i j}$ та $E_{i}$ використовуються наступні формули: $E_{i j}=\sum_{l=1}^{L_{1}} \prod_{l=1}^{L_{1}} k_{j l} p_{i j l} \quad E_{i}=\sum_{i=1}^{M} r_{j} E_{i j}$ 
Таблиця 6

\begin{tabular}{|c|c|c|c|c|}
\hline & Вертоліт для & \multicolumn{3}{|c|}{ Вертольоти, що розглядаються для вибору } \\
\hline Характеристики & Mi-8MT & Мі-8МСБ-В & AW-149 & NH90 \\
\hline Маса злітнамакс., кг & 13000 & 12500 & 8600 & 10600 \\
\hline $\begin{array}{l}\text { Швидкість } \\
\text { крейсерська, км/год }\end{array}$ & 240 & 240 & 287 & 280 \\
\hline $\begin{array}{ll}\text { Практична } & \text { дальність } \\
\text { польоту, км } & \\
\end{array}$ & 610 & 600 & 800 & 800 \\
\hline Практична стеля, м & 5000 & 8000 & 2700 & 6000 \\
\hline $\begin{array}{l}\text { Корисне } \\
\text { навантаження, кг }\end{array}$ & $\begin{array}{c}\text { До } 24 \text { чол. або } 12 \\
\text { поранених, або } \\
\text { 4000кг вантажу }\end{array}$ & $\begin{array}{l}\text { До } 24 \text { чол. або } 12 \\
\text { поранених, або } \\
\text { 5000кг вантажу }\end{array}$ & До 18 чол & $2500 \kappa г$ \\
\hline Вартість, млн. \$ & 17 & 9 & 13 & 32 \\
\hline Озброєння & $\begin{array}{c}\text { Підвісні контейнери } \\
\text { з РС, кулемет }\end{array}$ & $\begin{array}{c}\text { Підвісні контейнери } \\
\text { з РС, кулемет }\end{array}$ & $\begin{array}{c}\text { Підвісні контейнери } \\
\text { з РС, кулемет }\end{array}$ & $\begin{array}{c}\text { Торпеда, бомби } \\
\text { різного типу, } \\
\text { ракети + }\end{array}$ \\
\hline Інше & $\begin{array}{c}\text { Система пасивного } \\
\text { захисту (кутові } \\
\text { відбивачі) } \\
\end{array}$ & $\begin{array}{c}\text { Система пасивного } \\
\text { захисту (кутові } \\
\text { відбивачі), ... } \\
\end{array}$ & $\begin{array}{c}\text { Система пасивного } \\
\text { захисту (кутові } \\
\text { відбивачі) } \\
\end{array}$ & $\begin{array}{c}\text { Система } \\
\text { пасивного захисту } \\
\text { (кутові відбивачі) }\end{array}$ \\
\hline
\end{tabular}

Таблиця 7

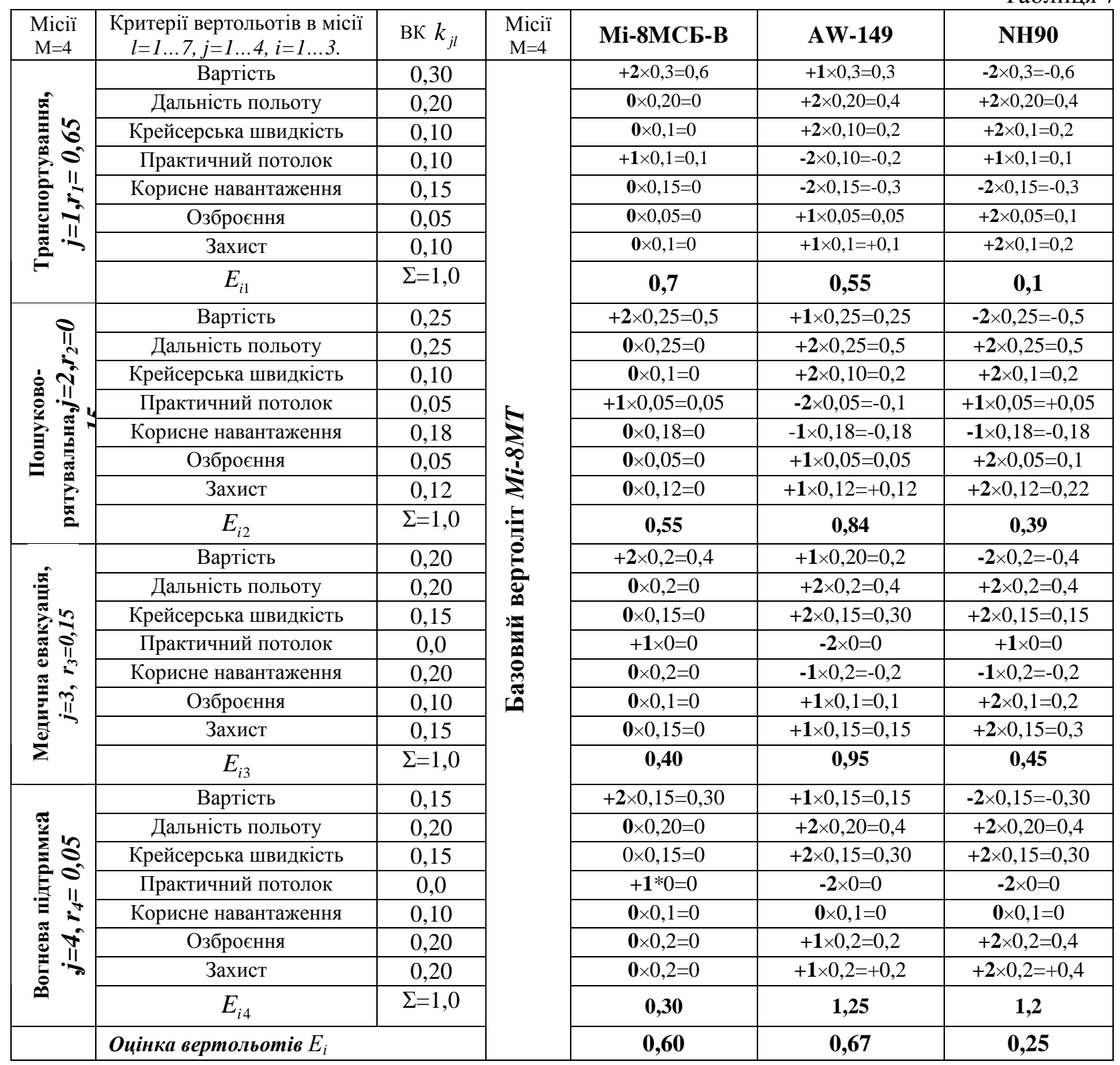


Як показують результати оцінок вертольоти AW-149 та Mi-8MSB-B (як транспортні вертольоти) є пріоритетними для вибору завдяки їх невисокій вартості, високій стелі польоту (особливо Mi-8MSB-B) та корисному навантаженню. NH-90 втрачає через свою високу вартість. У нашому випадку критерій вартості має високу вагу. Для іншого покупця така вартість може не бути таким важливим показником, що призведе до меншої його ваги і в результаті $\mathrm{NH}-90$ отримає більш високий пріоритет. Конструктивний аналіз властивостей вертольотів при їх застосуванні у різних сценаріях/місіях дозволяє доволі простим способом та наглядно визначити їх сильні та слабкі сторони. Для прийняття остаточного рішення рекомендується проаналізувати властивості зазначених вертольотів методом багатокритеріального аналізу за стратегіями “Цінність для військ” та “Можливість підтримувати їх боєготовність протягом визначеного терміну".

Висновки. Наведені методи та приклади їх застосування підтверджують доцільність їх застосування для вирішення широкого кола практичних завдань раціонального вибору, використовуючи як експертні оцінки так і результати аналітичних та експериментальних оцінок. Комбінація експертних припущень та аналітичних розрахунків $є$ позитивною стороною. Вона дозволяє ще в процесі оцінки варіантів виявляти сильні та слабкі сторони кожного 3 них, опрацьовувати альтернативні рішення.

Також слід зауважити, що людський чинник відіграє важливу роль (як позитивну так i негативну) при прийнятті рішень. Зазначені методи дозволяють кількісно оцінити такий вплив. Вони $\epsilon$ простими, наглядними та дозволяють отримати практичний результат за короткий термін.

\section{СПИСОК ВИКОРИСТАНОЇ ЛІТЕРАТУРИ}

1. Т. Саати. Принятие решений. Метод анализа иерархий. М., "Радио и связь”. 1993.

2. Застосування методів багатокритеріальної оптимізації для вирішення задачі розподілу вагонів по вантажним фронтам / Ю. В. Чибісов, Ю. C. Шульга // Збірник наукових праць Дніпропетровського національного університету залізничного транспорту імені академіка В. Лазаряна. Транспортні системи та технології перевезень. - 2014. - Вип. 7. - С. 65-72.

3. Багатокритеріальний аналіз ефективності портфелів наукових проектів вищого навчального закладу / І. Є. Драч, Г. Л. Свтушенко // Управління розвитком складних систем. - 2015. - Вип. 22(1). C. 33-41.

4. Багатокритеріальний вибір систем захисту інформації за допомогою нечітких парних порівнянь альтернатив / О. В. Шматко, С. В. Сичев // Системи обробки інформації. - 2011. - Вип. 3. C. 161-164.

Стаття надійшла до редакції 13.07.2017

Корендович В. С., к.Т.н., доцент

Центр военно-стратегических исследований Национального университета обороны Украины имени Ивана Черняховского, Киев

Применение многокритериального анализа для приоритетного выбора

Резюме. В статье приведены методы многокритериального анализа по нескольким стратегиям для поддержки принятия решения по выбору наиболее приемлемого варианта.

Ключевые слова:многокритериальный анализ, стратегия выбора, оценка систем.

V. Korendovych, Ph.D, assistant professor

Center for Military and Strategic Studies of the National Defence University of Ukraine named after Ivan Chernyhovsky, Kyiv

\section{The Use of Multi Criteria Analysis for Prioritization Choice}

Resume: The article make the examples of multi criteria analysis which support making decision for prioritization choice.

Keywords: multi criteria analysis; strategy of choice; assessment of systems. 